\title{
Imagining a Gold Open Access Future: Attitudes, Behaviors, and Funding Scenarios among Authors of Academic Scholarship
}

\author{
Carol Tenopir, Elizabeth D. Dalton, Lisa Christian, \\ Misty K. Jones, Mark McCabe, MacKenzie Smith, and \\ Allison Fish
}

The viability of gold open access publishing models into the future will depend, in part, on the attitudes of authors toward open access (OA). In a survey of academics at four major research universities in North America, we examine academic authors' opinions and behaviors toward gold OA. The study allows us to see what academics know and perceive about open access models, their current behavior in regard to publishing in OA, and possible future behavior. In particular, we gauge current attitudes to examine the perceived likelihood of various outcomes in an all-open access publishing scenario. We also survey how much authors at these types of universities would be willing to pay for article processing charges (APCs) from different sources. Although the loudest voices may often be heard, in reality there is a wide range of attitudes and behaviors toward publishing. Understanding the range of perceptions, opinions, and behaviors among academics toward gold OA is important for academic librarians who must examine how $O A$ serves their research communities, to prepare for an OA future, and to understand how OA impacts the library's role.

\section{Introduction}

Open access is often predicted to be the future of academic publishing. ${ }^{1}$ This statement is loaded with idealism and complications, carrying within itself the full weight of the anxieties of scholars, publishers, and librarians. In fact, Hoyt and Binfield proclaim

Carol Tenopir is Chancellor's Professor in the School of Information Sciences at the University of Tennessee-Knoxville; e-mail: ctenopir@utk.edu. Elizabeth D. Dalton is an Assistant Professor at Middle Tennessee State University; e-mail: Elizabeth.Dalton@mtsu.edu. Lisa Christian and Misty K. Jones are Research Associates at the University of Tennessee-Knoxville; e-mail: lchrist2@utk.edu, mlitton@utk.edu. Mark McCabe is Professor \& Director of the Digital Business Program, SKEMA Business School, and Lecturer, Questrom School of Business, Boston University; e-mail: prof.mark.mccabe@gmail.com. MacKenzie Smith is University Librarian at the University of California-Davis; e-mail: macsmith@ucdavis.edu. Allison Fish is Assistant Professor at Indiana University-Bloomington; e-mail: allifish@indiana.edu. (C2017 Carol Tenopir, Elizabeth D. Dalton, Lisa Christian, Misty K. Jones, Mark McCabe, MacKenzie Smith, and Allison Fish, Attribution-NonCommercial (http://creativecommons.org/licenses/by-nc/4.0/) CC BY-NC. 
"we are in the midst of a change so expansive that we don't quite know how to adapt to it," ${ }^{2}$ while Zhao contends that it "has begun to reshape the landscape of scholarly publishing." ${ }^{3}$ Many academics talk about open access (OA) for its democratizing possibilities, ${ }^{4}$ contending that scholarship is an endeavor in public service and its fruits should be available to all scholars and interested parties. ${ }^{5}$

Rising subscription costs and ever-restrictive library budgets also seem to support $\mathrm{OA}$ as a viable alternative publishing model-whether this model be green, gold, or hybrid open access. ${ }^{6}$ Yet, open access carries its own concerns: costs associated with article processing charges (APCs) for gold or hybrid open access journals, the costs of implementing or maintaining institutional repositories for green open access, the associative impact upon academics' ability to publish, concerns about the quality of peer review, and the rise of predatory journals. ${ }^{7}$ But perhaps the most pressing concern for academic librarians is: What is the role for academic libraries in a gold open access future? This study explores the attitudes, perceptions, and behaviors of academic researchers toward gold OA to bring their voices to the library discussion.

As libraries are ever more pressed to justify expenditures and to make difficult budgetary decisions, the OA movement allows them to proactively redefine or refine their roles within this nascent publishing model. ${ }^{8}$ Libraries have the opportunity to influence the conversation concerning the adoption of OA in their communities, furthering their traditional roles as advocates and educators in adapting outreach services, programs, and workshops to address faculty and student concerns. ${ }^{9}$ To examine how libraries may adapt and change their roles and services in this evolving scholarly publishing environment, we conducted surveys of faculty, graduate students, and postdoctoral researchers at four North American research-intensive universities. We asked respondents what was most important to them in deciding where to publish their work, including various journal factors and access to potential stakeholders and audience, as well as their familiarity with open access, and how much they are willing to pay regarding article processing charges (APCs). We hope that our findings will contribute to the ongoing conversations surrounding viable open access models as well as assisting librarians as they develop new services and programs to inform or serve their faculty and graduate students. In this project, we focus on gold open access and provide six main takeaways for academic libraries to consider as this model becomes widespread. The survey discussed here is part of a larger project called Pay It Forward, funded by the Andrew W. Mellon Foundation to the University of California, Davis, to examine the full implications in an imagined complete gold OA future, including not only behavioral and service implications, but also cost implications to research institutions. The full report of the Pay It Forward project may be found at the University of California, Davis's Innovating Communication in Scholarship website. ${ }^{10}$

\section{Literature Review}

Within the last several years, many studies have shown that academics' awareness of open access journals has steadily increased. ${ }^{11}$ However, awareness does not always equate to understanding or acceptance of OA and its different models. As Beall, ${ }^{12}$ Butler, ${ }^{13}$ and Zhao ${ }^{14}$ contend, the rise of open access, particularly gold open access, coincides with the rise of new predatory journals, whose aim is the creation of profit rather than the dissemination of knowledge- at the expense of scholarship. These predatory journals often have little to no peer review. In authors' or readers' minds, gold OA and predatory journals may be confused. In light of this circumstance, suspicion toward the use of APCs in gold OA is understandable. Lack of understanding the different models of OA sometimes leads academics to doubt its credibility. ${ }^{15}$ Even when they recognize the publisher of a legitimate OA journal, they may still doubt the 
model that requires an APC, and worry that the APC structure may tempt publishers to accept more and lower-quality articles to drive revenue. ${ }^{16}$

This confusion, however, provides libraries with an opportunity to redefine or adapt their roles within the changing scholarly publishing environment. In Malefant's study of the outreach duties of liaison librarians, she contends that "mainstreaming" scholarly communication is essential for moving the profession forward, marrying scholarly communication with information literacy. ${ }^{17}$ Zhao calls this intersection between scholarly communication and education initiatives "scholarly publishing literacy," ${ }^{18}$ while ACRL terms it "information fluency," distinguishing it from information literacy by its extension into intellectual property rights and laws and the publishing process itself. ${ }^{19}$ This is a shift in the conception of librarianship itself. It is a holistic view of literacy that highlights the importance of librarians at the heart of scholarship.

As leaders and educators, librarians will need to form new collaborative partnerships, beyond those traditional relationships forged through liaison librarians for purposes of collection development and teaching. Bonn calls for partnerships with university presses, law schools, and offices of research that will allow libraries to offer valuable new services and resources for dissemination, continuing education, and intellectual property law. ${ }^{20}$ However, education and collaborative relationships are not the only way for libraries to provide critical scholarly communication services for their patrons. Article processing charges (APCs) can be obstacles for faculty and students. Authors sometimes turn to their libraries for guidance or funds through the development of a library consortia or a library funding model to help cover APCs. ${ }^{21}$

\section{Methods}

\section{Questionnaire Development}

Between February and May 2015, the researchers conducted focus groups of graduate students, postdoctoral researchers, and faculty at each participating university to gain a fuller picture of academics' understanding and opinions regarding open access publishing models. The data from these focus groups contributed to the development of the current survey questionnaire, the goal of which was to gain a broader, more generalizable understanding of these issues. The researchers incorporated the themes, vocabulary, and scenarios that emerged from focus group discussions as guiding constructs in survey question development. The research team, with additional input and approval from the economic modeling team and principal investigator, developed the survey questionnaire during the month of May 2015. After several rounds of development and testing, the final questionnaire (depending on skip and display logic routes of participant answers) ranged from 20 to 30 questions. The full questionnaire can be found in the University of Tennessee's institutional repository, TRACE. ${ }^{22}$

\section{Sample}

The researchers sought to achieve a representation of academics, including faculty, graduate students, and postdoctoral researchers, across a broad range of subject disciplines from the four participating research-intensive universities (University of British Columbia-Vancouver, University of California-Davis, University of California-Irvine, Ohio State University). These universities are believed to be representative of the broader population of large academic research institutions in the United States and Canada. The criterion for inclusion stated that respondents must be either employed as faculty/staff or be enrolled as a graduate student at the university. The survey was distributed to a total of approximately 15,000 academics. With 2,121 responses, the overall response rate was approximately 14.1 percent. 


\section{Procedures}

IRB approval was obtained by the University of Tennessee, Institutional Review Board for human subjects compliance with independent approval also obtained at each of the participating institutions. An informed consent statement was included as the first page of the survey. Respondents provided consent by clicking "next" after reading the statement. As a participation incentive, the recruitment e-mail and the informed consent statement informed participants of the option to be included in a prize drawing for an iPad Mini. At the end of the survey, they had the option to be redirected to a new, separate page where e-mail addresses would be collected for the prize drawing.

The researchers used Qualtrics software to develop and distribute the survey. Pilot test links were first sent to a small subsample of academic researchers at the participating universities. Pilot testing was also conducted in person with local university researchers and graduate students. With the initial pilot test data, the researchers ensured that questionnaire language was clear, the sequential ordering of questions was logical, and there were no technical problems with the survey link.

After pilot testing, live links were sent to librarian distributors at the four participating universities. Those distributors then sent the links to targeted e-mail distribution lists. These lists were chosen with the goal of ensuring roughly equivalent sampling across different disciplines and position types. The survey was open for responses for approximately three weeks, from May 20, 2015, to June 10, 2015. Two weeks after the initial survey launch, the librarian distributors sent a reminder e-mail thanking those who had already participated and reminding others of their opportunity to participate. The final number of respondents was 2,121. After cleaning the data, which included removing all respondents who did not provide at least one independent variable response and one dependent variable response, the final $n=2,021$. The researchers analyzed the data using the IBM SPSS Statistics version 22 package.

\section{Variables}

The survey asked a series of basic demographic questions related to respondents' degrees, position at the university, and subject discipline. Within this study, the researchers examined opinions about open access publishing, the feasibility of specific outcomes in an all-open access scenario, and the amounts that respondents would be willing to pay for article processing charges (APCs). Differences in position and subject discipline were also explored to determine how these impacted responses. The options for "position" included faculty, graduate student, postdoctoral researcher, or other. After cleaning, the researchers decided to merge the small number of respondents who specified "other" with postdoctoral researchers, since most were clinical residents within medical schools. Of the respondents, 46.3 percent were faculty, 45.3 percent were graduate students, and 8.4 percent were postdoctoral researchers. Options for "area of study" included arts and humanities, engineering and computer sciences, life sciences/medicine, mathematics, physical sciences, social sciences, or other. Respondents then wrote in their specific subject discipline within that area of study. If they selected "other" and then wrote in a specific subject discipline, the researchers recoded them into the appropriate area of study. Area of study will be referred to as "subject discipline" within this paper. A recently published article from the Pay It Forward project examines survey questions pertaining to the different journal attributes that aide authors at large research-intensive universities in choosing publishing outlets - such as quality and reputation of journal, impact factor, audience, scope of the journal, and whether it is open access. ${ }^{23}$

Dependent variables of interest within this study are open access opinions, open access scenarios, and maximum APCs. Open access opinions refers to a set of three ideas about 
open access that emerged as common themes within the focus groups conducted prior to the survey. These include "Paying article processing charges for Open Access is a reasonable alternative to subscription fees"; "In general, articles published in Open Access journals are of lower quality than those published in subscription based journals"; and "In general, the amount of an article processing charge reflects the quality of the journal." These items were included to gauge the valence of opinions toward open access publishing issues. Open access scenarios include six possible outcomes of a hypothetical future scenario where open access was the dominant publishing model. These include "My ability to publish would be limited"; "More people would read and use my research"; "The overall quality of published research would increase"; "People from institutions with less funding would have limited ability to publish"; "I would find alternative ways to publish my research"; and "There would be increased media coverage of scholarly research."

Finally, Maximum APC asked respondents what they thought the maximum reasonable APC range is for each of the following possible funding sources: "Your own personal funds"; "Your discretionary research funds"; "An open access publication fund through the library"; "Departmental or other institutional research funds"; and "Grant funds." The options for ranges were none, less than $\$ 100, \$ 100-\$ 499$, \$500-\$999, \$1,000-\$1,999, \$2,000$\$ 2,999, \$ 3,000-\$ 3,999$, or $\$ 4,000$ or more.

\section{Results}

\section{Open Access Opinions}

As can be seen in table 1, overall agreement with each of the three statements about OA and APCs shows neutral to

\begin{tabular}{|l|c|c|}
\hline \multicolumn{3}{|c|}{ TABLE 1 } \\
Open Access Opinions (1=Disagree \\
Strongly, 5=Agree Strongly) \\
\hline & M & SD \\
\hline APCs reasonable alternative & 2.86 & 1.24 \\
\hline OA journals are lower quality & 3.00 & 1.29 \\
\hline APCs reflect quality of journal & 2.08 & 1.17 \\
\hline
\end{tabular}
somewhat negative opinions toward gold OA. On a scale of 1-5, where 1 was "disagree strongly" and 5 was "agree strongly," respondents disagreed somewhat $(\mathrm{M}=2.86)$ with the idea that paying article processing charges for Open Access is a reasonable alternative to subscription fees. With a mean of 3.00, respondents were overall neutral to the idea that in general, articles published in Open Access journals are of lower quality than those published in subscription-based journals. They disagreed

\begin{tabular}{|c|c|c|c|c|c|c|c|c|}
\hline \multicolumn{9}{|c|}{$\begin{array}{c}\text { TABLE } 2 \\
\text { Open Access Opinions by Position (ANOVA) }\end{array}$} \\
\hline \multirow[t]{3}{*}{ Opinion } & \multicolumn{6}{|c|}{ Position Type } & \multirow[t]{3}{*}{$\mathrm{F}$} & \multirow{3}{*}{$\eta_{p}^{2}$} \\
\hline & \multicolumn{2}{|c|}{ Faculty } & \multicolumn{2}{|c|}{ Postdoc/Other } & \multicolumn{2}{|c|}{ Grad Students } & & \\
\hline & mean & $95 \% C I$ & mean & $95 \% C I$ & mean & $95 \% C I$ & & \\
\hline $\begin{array}{l}\text { APCs } \\
\text { reasonable } \\
\text { alternative }\end{array}$ & 2.80 & $\begin{array}{c}2.70- \\
2.90\end{array}$ & 3.29 & $\begin{array}{c}3.07- \\
3.51\end{array}$ & 2.99 & $\begin{array}{c}2.88- \\
3.10\end{array}$ & $9.01 *$ & .016 \\
\hline $\begin{array}{l}\text { OA journals } \\
\text { lower quality }\end{array}$ & 3.08 & $\begin{array}{c}2.97- \\
3.19\end{array}$ & 2.65 & $\begin{array}{c}2.42- \\
2.88\end{array}$ & 2.89 & $\begin{array}{c}2.77- \\
3.00\end{array}$ & $6.67 * *$ & .012 \\
\hline $\begin{array}{l}\text { APCs reflect } \\
\text { quality of } \\
\text { journal }\end{array}$ & 1.96 & $\begin{array}{l}1.86- \\
2.06\end{array}$ & 1.96 & $\begin{array}{l}1.75- \\
2.17\end{array}$ & 2.41 & $\begin{array}{c}2.30- \\
2.51\end{array}$ & $20.57 *$ & .035 \\
\hline \multicolumn{9}{|c|}{$\begin{array}{l}\text { MANOVA: } F[6,2270]=12.671, p<.001 \text {, Wilks'Lambda=.936, partial eta squared=.032; } \\
*_{p}<.001 ; * * p=.001\end{array}$} \\
\hline
\end{tabular}




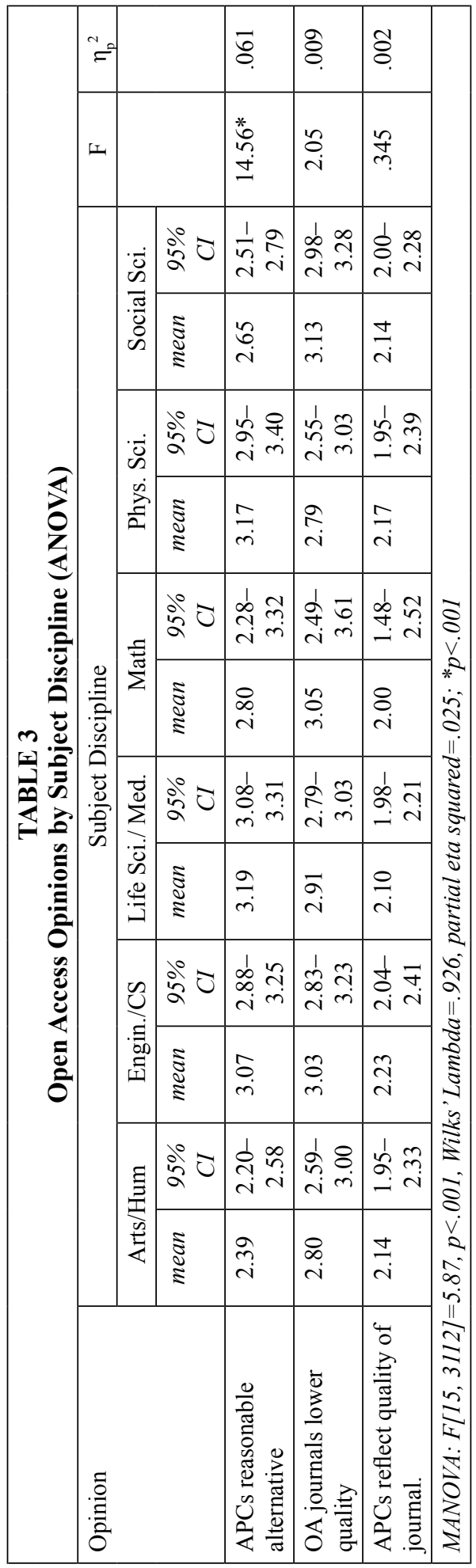

overall that in general, the amount of an article processing charge reflects the quality of the journal $(\mathrm{M}=2.08)$. However, because of the range of different practices, resources, and experiences among those in different position types and subject disciplines, there is a greater range of agreement with these statements to be explored. Using multiple analyses of variance and Tukey's HSD for post-hoc analyses, all significant differences across position types and subject disciplines are based on an alpha of 0.05 . Footnotes provide significance levels for differences between individual position types and subject disciplines, but all reported results are significant at the $P<0.05$ level. However, we caution that mean differences should also be noted (see tables 2, 3, 5, and 6) for the purposes of evaluating substantive, meaningful differences between groups. ${ }^{24}$

In terms of position types, there are distinct differences in agreement for each stated opinion (see table 2). It is clear that the type of position in which a researcher is working has some impact on how they view these aspects of open access publishing. While postdocs, whose positions may be funded by large grants, are most likely to believe that paying APCs is a reasonable practice, faculty tend to be more dubious about the quality of articles published in OA journals. Graduate students, on the other hand, more readily equate higher APCs with higher quality. Specifically, postdoctoral researchers/other feel somewhat more strongly than faculty ${ }^{25}$ and graduate students ${ }^{26}$ that paying article processing charges for Open Access is a reasonable alternative to subscription fees. But when it comes to the idea that articles published in Open Access journals are of lower quality than those published in subscription-based journals, it is faculty who express the strongest agreement. ${ }^{27}$ Finally, graduate students agree more strongly than both faculty ${ }^{28}$ and postdoctoral researchers/others ${ }^{29}$ that the amount of an article processing charge reflects the quality of the journal. 


\begin{tabular}{|c|c|c|}
\hline \multicolumn{3}{|c|}{$\begin{array}{c}\text { TABLE } 4 \\
\text { Open Access Scenarios (1=Disagree Strongly, } \\
\text { 5=Agree Strongly) }\end{array}$} \\
\hline & $\mathbf{M}$ & SD \\
\hline Ability to publish limited & 3.24 & 1.30 \\
\hline More people read research & 3.36 & 1.28 \\
\hline Quality of research increase & 2.46 & 1.08 \\
\hline Less funding=limited ability to publish & 4.14 & 1.00 \\
\hline Find alternative ways to publish & 3.16 & 1.21 \\
\hline Increased media coverage & 2.74 & 1.26 \\
\hline
\end{tabular}

There are also distinct differences of opinion across subject disciplines (see table 3). Not surprisingly, it appears that paying APCs is a more accepted publishing practice within the disciplines of engineering/ computer science, life sciences/ medicine, and physical sciences than it is in arts/humanities or social sciences. Academics from arts/humanities and social sciences express significantly lower agreement than other subject disciplines ${ }^{30}$ that paying article processing charges for Open Access is a reasonable alternative to subscription fees. But these two subject areas differ somewhat when it comes to the idea that articles published in Open Access journals are of lower quality than those published in subscription-based journals, with those from social science agreeing slightly more with this statement than those from arts/humanities. ${ }^{31}$

\section{Open Access Scenarios}

Respondents were asked to imagine a future in which open access with APC payment was the dominant publishing model. They were then asked how strongly they agree with the likelihood of six different possible outcomes of this scenario. Overall, respondents feel most strongly that this model would limit the publishing abilities of those at institutions with less funding (see table 4). They also agree somewhat that their own ability to publish would be limited, and they would find alternative ways to publish. At the same time, they also agree somewhat that their research would be more widely read and used in an all-open access scenario. But they disagree somewhat that published research

\begin{tabular}{|c|c|c|c|c|c|c|c|c|}
\hline \multicolumn{9}{|c|}{$\begin{array}{c}\text { TABLE } 5 \\
\text { Open Access Scenarios by Position (ANOVA) }\end{array}$} \\
\hline \multirow[t]{3}{*}{ Scenario } & \multicolumn{6}{|c|}{ Position type } & \multirow[t]{3}{*}{$\mathrm{F}$} & \multirow[t]{3}{*}{$\eta_{p}^{2}$} \\
\hline & \multicolumn{2}{|c|}{ Faculty } & \multicolumn{2}{|c|}{ Postdoc/Other } & \multicolumn{2}{|c|}{ Grad Students } & & \\
\hline & mean & $95 \% C I$ & mean & $95 \% C I$ & mean & $95 \% C I$ & & \\
\hline $\begin{array}{l}\text { Ability to publish } \\
\text { limited }\end{array}$ & 3.26 & $\begin{array}{c}3.15- \\
3.37\end{array}$ & 3.02 & $\begin{array}{c}2.77- \\
3.27\end{array}$ & 3.18 & $\begin{array}{c}3.06- \\
3.31\end{array}$ & 1.69 & .003 \\
\hline $\begin{array}{l}\text { More people read } \\
\text { research }\end{array}$ & 2.98 & $\begin{array}{c}2.88- \\
3.09\end{array}$ & 3.87 & $\begin{array}{c}3.63- \\
4.10\end{array}$ & 3.47 & $\begin{array}{c}3.35- \\
3.59\end{array}$ & $32.20 *$ & .057 \\
\hline $\begin{array}{l}\text { Quality of research } \\
\text { increase }\end{array}$ & 2.25 & $\begin{array}{l}2.16- \\
2.33\end{array}$ & 2.87 & $\begin{array}{c}2.67- \\
3.07\end{array}$ & 2.73 & $\begin{array}{c}2.63- \\
2.83\end{array}$ & $33.28 *$ & .058 \\
\hline $\begin{array}{l}\text { Less funding=limited } \\
\text { ability to publish }\end{array}$ & 4.19 & $\begin{array}{c}4.10- \\
4.27\end{array}$ & 4.03 & $\begin{array}{c}3.83- \\
4.23\end{array}$ & 3.89 & $\begin{array}{c}3.79- \\
3.99\end{array}$ & $9.79 *$ & .018 \\
\hline $\begin{array}{l}\text { Find alternative ways } \\
\text { to publish }\end{array}$ & 3.19 & $\begin{array}{c}3.09- \\
3.29\end{array}$ & 3.15 & $\begin{array}{c}2.92- \\
3.39\end{array}$ & 3.16 & $\begin{array}{c}3.04- \\
3.27\end{array}$ & .087 & .000 \\
\hline $\begin{array}{l}\text { Increased media } \\
\text { coverage }\end{array}$ & 2.38 & $\begin{array}{c}2.28- \\
2.48\end{array}$ & 3.23 & $\begin{array}{c}3.00- \\
3.46\end{array}$ & 3.04 & $\begin{array}{c}2.93- \\
3.15\end{array}$ & $47.01 *$ & .081 \\
\hline
\end{tabular}




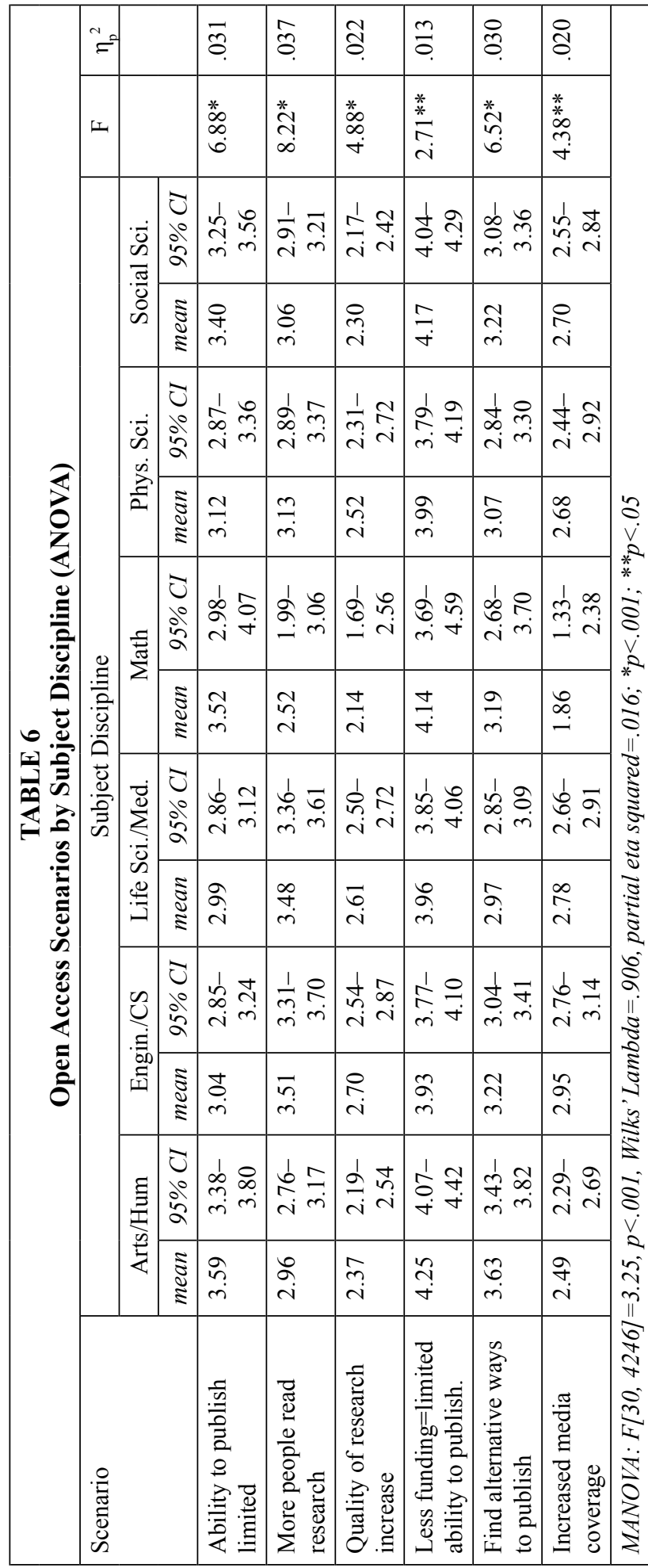

would increase in quality and that media coverage of research would increase.

Faculty, graduate students, and postdoctoral researchers/other saw the likelihood of some of these outcomes differently (see table 5). It seems that faculty view this hypothetical all-OA future more negatively than both graduate students and postdoctoral researchers/ other. Specifically, faculty expressed lower agreement than both graduate students ${ }^{32}$ and postdoctoral researchers/other ${ }^{33}$ that more people would read and use my research, that the overall quality of published research would increase, and that there would be increased media coverage of scholarly research. Faculty expressed slightly higher agreement than graduate students ${ }^{34}$ and postdoctoral researchers/other ${ }^{35}$ with the idea that people from institutions with less funding would have limited ability to publish.

The scenarios are viewed differently by the different disciplines, with a divide between those from arts/humanities, social sciences, and math and those from engineering/ CS, life sciences/medicine, and physical sciences (see table 6). Although differences are not huge, those from arts/humanities and social sciences feel somewhat more strongly that an all-OA scenario would make publishing more difficult for both themselves 
and for people from institutions with less funding. Specifically, they express higher agreement that my ability to publish would be limited than those in engineering/CS, ${ }^{36}$ life sciences, ${ }^{37}$ and physical sciences ${ }^{38}$ and that people from institutions with less funding would have limited ability to publish than those in engineering $/ \mathrm{CS}^{39}$ and life sciences/medicine.$^{40} \mathrm{It}$ follows that people from arts/humanities and social sciences are more likely to seek out alternative publishing outlets in this scenario. Specifically, arts/humanities ${ }^{41}$ and social sciences $^{42}$ express higher agreement than those in life sciences/medicine that $I$ would find alternative ways to publish my research; those in arts/humanities also express higher agreement with this statement than those in physical sciences. ${ }^{43}$

Those from life sciences/medicine and engineering/CS, on the other hand, believe that an all-OA scenario would increase their readership and that research overall would increase in quality. Results show that life sciences/medicine agree somewhat more strongly than those in arts/humanities, ${ }^{44}$ math ${ }^{45}$ and social sciences ${ }^{46}$ that more people would read and use my research. Those in engineering/CS also express higher agreement with this statement than those in mathematics ${ }^{47}$ and social sciences. ${ }^{48}$ Those in engineering/CS ${ }^{49}$ and life sciences/medicine ${ }^{50}$ agree more strongly than those in social science that the overall quality of published research would increase. Finally, those in engineering/CS, ${ }^{51}$ life sciences/ medicine, ${ }^{52}$ and social science ${ }^{53}$ express significantly more agreement with the statement that there would be increased media coverage of scholarly research than those in arts/humanities.

\begin{tabular}{|c|c|c|c|c|c|c|c|c|c|}
\hline \multicolumn{10}{|c|}{$\begin{array}{c}\text { TABLE } 7 \\
\text { Frequency, Percentage, and Adjusted Standardized Residuals for Each APC } \\
\text { Source }\end{array}$} \\
\hline \multirow{2}{*}{$\begin{array}{l}\text { Source of } \\
\text { APC }\end{array}$} & \multicolumn{9}{|c|}{ Highest Reasonable APC amount } \\
\hline & None & $\begin{array}{l}\text { Less } \\
\text { than } \\
\$ 100\end{array}$ & $\begin{array}{c}\$ 100 \\
\$ 499\end{array}$ & $\begin{array}{c}\$ 500- \\
\$ 999\end{array}$ & $\begin{array}{c}\$ 1,000- \\
\$ 1,999\end{array}$ & $\begin{array}{c}\$ 2,000- \\
\$ 2,999\end{array}$ & $\begin{array}{c}\$ 3,000- \\
\$ 3,999\end{array}$ & $\begin{array}{l}\$ 4,000 \\
\text { or } \\
\text { more }\end{array}$ & Total \\
\hline \multirow{3}{*}{$\begin{array}{l}\text { Personal } \\
\text { funds }\end{array}$} & 975 & 558 & 173 & 45 & 12 & 2 & 0 & 1 & 1,766 \\
\hline & $55.2 \%$ & $31.6 \%$ & $9.8 \%$ & $2.5 \%$ & $0.7 \%$ & $0.1 \%$ & $0.0 \%$ & $0.1 \%$ & $100.0 \%$ \\
\hline & 29.2 & 7.1 & -14.4 & -12.8 & -11.0 & -12.3 & -2.3 & -3.1 & \\
\hline \multirow{3}{*}{$\begin{array}{l}\text { Discretionary } \\
\text { funds }\end{array}$} & 355 & 514 & 536 & 218 & 103 & 15 & 3 & 5 & 1,749 \\
\hline & $20.3 \%$ & $29.4 \%$ & $30.6 \%$ & $12.5 \%$ & $5.9 \%$ & $0.9 \%$ & $0.2 \%$ & $0.3 \%$ & $100.0 \%$ \\
\hline & -7.5 & 4.7 & 9.0 & 2.0 & -1.0 & -10.8 & -.6 & -1.6 & \\
\hline \multirow{3}{*}{$\begin{array}{l}\text { OA fund } \\
\text { through } \\
\text { library }\end{array}$} & 564 & 331 & 252 & 132 & 53 & 460 & 0 & 0 & 1,792 \\
\hline & $31.5 \%$ & $18.5 \%$ & $14.1 \%$ & $7.4 \%$ & $3.0 \%$ & $25.7 \%$ & $0.0 \%$ & $0.0 \%$ & $100.0 \%$ \\
\hline & 4.2 & -7.2 & -9.7 & -5.7 & -6.7 & 36.5 & -2.3 & -3.5 & \\
\hline \multirow{3}{*}{$\begin{array}{l}\text { Departmental } \\
\text { funds }\end{array}$} & 256 & 411 & 525 & 294 & 183 & 43 & 7 & 24 & 1,743 \\
\hline & $14.7 \%$ & $23.6 \%$ & $30.1 \%$ & $16.9 \%$ & $10.5 \%$ & $2.5 \%$ & $0.4 \%$ & $1.4 \%$ & $100.0 \%$ \\
\hline & -13.4 & -1.6 & 8.4 & 8.5 & 7.8 & -7.7 & 1.6 & 5.3 & \\
\hline \multirow[t]{3}{*}{ Grant funds } & 270 & 390 & 501 & 289 & 211 & 60 & 11 & 18 & 1,750 \\
\hline & $15.4 \%$ & $22.3 \%$ & $28.6 \%$ & $16.5 \%$ & $12.1 \%$ & $3.4 \%$ & $0.6 \%$ & $1.0 \%$ & $100.0 \%$ \\
\hline & -12.6 & -3.0 & 6.8 & 8.0 & 10.8 & -6.0 & 3.7 & 3.1 & \\
\hline Total & $\begin{array}{c}2420 \\
27.5 \%\end{array}$ & $\begin{array}{c}2204 \\
25.0 \%\end{array}$ & $\begin{array}{c}1987 \\
22.6 \%\end{array}$ & $\begin{array}{c}978 \\
11.1 \%\end{array}$ & $\begin{array}{c}562 \\
6.4 \%\end{array}$ & $\begin{array}{c}580 \\
6.6 \%\end{array}$ & $\begin{array}{c}21 \\
0.2 \%\end{array}$ & $\begin{array}{c}48 \\
0.5 \%\end{array}$ & $\begin{array}{c}8,800 \\
100.0 \%\end{array}$ \\
\hline
\end{tabular}

Pearson's chi-square: $X^{2}(28)=2952.34, p<.001$ 


\begin{tabular}{|c|c|c|c|c|c|c|c|c|}
\hline \multicolumn{9}{|c|}{$\begin{array}{c}\text { TABLE } 8 \\
\text { Frequency, Percentage, and Adjusted Standardized Residuals for Your Own } \\
\text { Personal Funds }\end{array}$} \\
\hline & \multicolumn{8}{|c|}{ Your Own Personal Funds } \\
\hline & None & $\begin{array}{l}\text { Less } \\
\text { than } \\
\$ 100\end{array}$ & $\begin{array}{l}\$ 100- \\
\$ 499\end{array}$ & $\begin{array}{c}\$ 500- \\
\$ 999\end{array}$ & $\begin{array}{c}\$ 1,000- \\
\$ 1,999\end{array}$ & $\begin{array}{l}\$ 2,000- \\
\$ 2,999\end{array}$ & $\begin{array}{l}\$ 4,000 \\
\text { or } \\
\text { more }\end{array}$ & Total \\
\hline \multirow{3}{*}{$\begin{array}{l}\text { Arts/ } \\
\text { Humanities }\end{array}$} & 190 & 102 & 16 & 1 & 1 & 0 & 0 & 310 \\
\hline & $61.3 \%$ & $32.9 \%$ & $5.2 \%$ & $0.3 \%$ & $0.3 \%$ & $0.0 \%$ & $0.0 \%$ & $100.0 \%$ \\
\hline & 2.4 & .5 & -3.0 & -2.7 & -.8 & -.7 & -.5 & \\
\hline \multirow{3}{*}{$\begin{array}{l}\text { Engineering/ } \\
\mathrm{CS}\end{array}$} & 123 & 75 & 30 & 4 & 2 & 0 & 0 & 234 \\
\hline & $52.6 \%$ & $32.1 \%$ & $12.8 \%$ & $1.7 \%$ & $0.9 \%$ & $0.0 \%$ & $0.0 \%$ & $100.0 \%$ \\
\hline & -.9 & .1 & 1.7 & -.9 & .3 & -.6 & -.4 & \\
\hline \multirow{3}{*}{$\begin{array}{l}\text { Life Sci./ } \\
\text { Medicine }\end{array}$} & 279 & 158 & 69 & 26 & 8 & 2 & 1 & 543 \\
\hline & $51.4 \%$ & $29.1 \%$ & $12.7 \%$ & $4.8 \%$ & $1.5 \%$ & $0.4 \%$ & $0.2 \%$ & $100.0 \%$ \\
\hline & -2.1 & -1.5 & 2.8 & 4.0 & 2.7 & 2.1 & 1.5 & \\
\hline \multirow[t]{3}{*}{ Mathematics } & 34 & 7 & 0 & 0 & 0 & 0 & 0 & 41 \\
\hline & $82.9 \%$ & $17.1 \%$ & $0.0 \%$ & $0.0 \%$ & $0.0 \%$ & $0.0 \%$ & $0.0 \%$ & $100.0 \%$ \\
\hline & 3.6 & -2.0 & -2.1 & -1.1 & -.5 & -.2 & -.2 & \\
\hline \multirow{3}{*}{$\begin{array}{l}\text { Physical } \\
\text { Sciences }\end{array}$} & 91 & 44 & 14 & 3 & 0 & 0 & 0 & 152 \\
\hline & $59.9 \%$ & $28.9 \%$ & $9.2 \%$ & $2.0 \%$ & $0.0 \%$ & $0.0 \%$ & $0.0 \%$ & $100.0 \%$ \\
\hline & 1.2 & -.7 & -.3 & -.5 & -1.1 & -.4 & -.3 & \\
\hline \multirow{3}{*}{$\begin{array}{l}\text { Social } \\
\text { Sciences }\end{array}$} & 252 & 170 & 43 & 11 & 1 & 0 & 0 & 477 \\
\hline & $52.8 \%$ & $35.6 \%$ & $9.0 \%$ & $2.3 \%$ & $0.2 \%$ & $0.0 \%$ & $0.0 \%$ & $100.0 \%$ \\
\hline & -1.2 & 2.2 & -.7 & -.4 & -1.5 & -.9 & -.6 & \\
\hline Total & $\begin{array}{c}969 \\
55.2 \%\end{array}$ & $\begin{array}{c}556 \\
31.6 \%\end{array}$ & $\begin{array}{c}172 \\
9.8 \%\end{array}$ & $\begin{array}{c}45 \\
2.6 \%\end{array}$ & $\begin{array}{c}12 \\
0.7 \%\end{array}$ & $\begin{array}{c}2 \\
0.1 \%\end{array}$ & $\begin{array}{c}1 \\
0.1 \%\end{array}$ & $\begin{array}{c}1757 \\
100.0 \%\end{array}$ \\
\hline
\end{tabular}

\section{Maximum APCs by Source}

Finally, we examined how much respondents would be willing to pay for APCs if the funding were to come from their personal funds, discretionary research funds, a library OA fund, departmental/institutional research funds, or grant funds (see table 7). Without doubt, the maximum range that respondents deem to be a reasonable APC amount varies according to the source of funds. For your own personal research funds, the majority of respondents have chosen "none" (55.2\%), followed by "less than $\$ 100$ " (31.6\%). If the source is your discretionary research funds, most have selected "less than $\$ 100$ " (29.4\%) or $\$ 100-\$ 499$ (30.6\%). The idea of funding APCs with an open access fund through the library is somewhat polarizing, with 31.5 percent choosing "none" and 25.7 percent jumping to $\$ 2,000-\$ 2,999$ as the maximum reasonable APC range. The highest chosen range for both departmental or other institutional funds $(30.1 \%)$ and grant funds $(28.6 \%)$ was $\$ 100-\$ 499$.

Due to possible differences in resources and practices, it is worth examining the highest reasonable APC amounts within each subject discipline for the various sources (see table 8). We look at the adjusted standardized residuals, which tell us the difference 
between the observed and expected values within the tables. The greater the residual amount, the greater that cell's contribution to the chi-square results. Residual amounts of greater than 2 or less than -2 indicate a lack of fit with the null, or expected, cell value. ${ }^{54}$ As the results below demonstrate, no matter what the source, those from arts/ humanities tend to want to pay less (or none) while those in life sciences/medicine are amenable to higher publishing costs.

In the case of funding coming from the participants themselves, within every discipline, more than half of the participants say that no APC amount is reasonable. Those from arts/humanities and mathematics are especially likely to have said "none," while those from life sciences/medicine are the only subject discipline from which participants selected “ $\$ 2,000-\$ 2,999$ " ( $n=2)$ or “ $\$ 4,000$ or more" ( $n=1)$.

If the source of funding is discretionary research funds, those from arts/humanities still overwhelmingly feel that "none" $(31.0 \%)$ or "less than $\$ 100$ " $(43.1 \%)$ is the highest reasonable amount to pay for APCs. Similarly, the most common amount social sciences choose is "less than $\$ 100$ " (37.5\%) (see table 9). In contrast, although the most common

\begin{tabular}{|c|c|c|c|c|c|c|c|c|c|}
\hline \multicolumn{10}{|c|}{$\begin{array}{c}\text { TABLE } 9 \\
\text { Frequency, Percentage, and Adjusted Standardized Residuals for Your } \\
\text { Discretionary Research Funds }\end{array}$} \\
\hline & \multicolumn{9}{|c|}{ Your Discretionary Research Funds } \\
\hline & None & $\begin{array}{l}\text { Less } \\
\text { than } \\
\$ 100\end{array}$ & $\begin{array}{c}\$ 100- \\
\$ 499\end{array}$ & $\begin{array}{c}\$ 500- \\
\$ 999\end{array}$ & $\begin{array}{c}\$ 1,000- \\
\$ 1,999\end{array}$ & $\begin{array}{c}\$ 2,000- \\
\$ 2,999\end{array}$ & $\begin{array}{c}\$ 3,000- \\
\$ 3,999\end{array}$ & $\begin{array}{l}\$ 4,000 \\
\text { or } \\
\text { more }\end{array}$ & Total \\
\hline \multirow{3}{*}{$\begin{array}{l}\text { Arts/ } \\
\text { Humanities }\end{array}$} & 95 & 132 & 67 & 9 & 3 & 0 & 0 & 0 & 306 \\
\hline & $31.0 \%$ & $43.1 \%$ & $21.9 \%$ & $2.9 \%$ & $1.0 \%$ & $0.0 \%$ & $0.0 \%$ & $0.0 \%$ & $100.0 \%$ \\
\hline & 5.2 & 5.9 & -3.7 & -5.6 & -4.0 & -1.8 & -.8 & -1.0 & \\
\hline \multirow{3}{*}{$\begin{array}{l}\text { Engineering/ } \\
\mathrm{CS}\end{array}$} & 46 & 57 & 91 & 24 & 8 & 2 & 0 & 1 & 229 \\
\hline & $20.1 \%$ & $24.9 \%$ & $39.7 \%$ & $10.5 \%$ & $3.5 \%$ & $0.9 \%$ & $0.0 \%$ & $0.4 \%$ & $100.0 \%$ \\
\hline & -.1 & -1.6 & 3.2 & -1.0 & -1.7 & .0 & -.7 & .5 & \\
\hline \multirow{3}{*}{$\begin{array}{l}\text { Life Sci./ } \\
\text { Medicine }\end{array}$} & 75 & 91 & 173 & 121 & 62 & 11 & 3 & 2 & 538 \\
\hline & $13.9 \%$ & $16.9 \%$ & $32.2 \%$ & $22.5 \%$ & $11.5 \%$ & $2.0 \%$ & $0.6 \%$ & $0.4 \%$ & $100.0 \%$ \\
\hline & -4.4 & -7.6 & .9 & 8.5 & 6.6 & 3.6 & 2.6 & .4 & \\
\hline \multirow[t]{3}{*}{ Mathematics } & 11 & 14 & 9 & 5 & 2 & 0 & 0 & 0 & 41 \\
\hline & $26.8 \%$ & $34.1 \%$ & $22.0 \%$ & $12.2 \%$ & $4.9 \%$ & $0.0 \%$ & $0.0 \%$ & $0.0 \%$ & $100.0 \%$ \\
\hline & 1.1 & .7 & -1.2 & -.1 & -.3 & -.6 & -.3 & -.3 & \\
\hline \multirow{3}{*}{$\begin{array}{l}\text { Physical } \\
\text { Sciences }\end{array}$} & 29 & 39 & 51 & 20 & 14 & 1 & 0 & 0 & 154 \\
\hline & $18.8 \%$ & $25.3 \%$ & $33.1 \%$ & $13.0 \%$ & $9.1 \%$ & $0.6 \%$ & $0.0 \%$ & $0.0 \%$ & $100.0 \%$ \\
\hline & -.5 & -1.1 & .7 & .2 & 1.7 & -.3 & -.5 & -.7 & \\
\hline \multirow{3}{*}{$\begin{array}{l}\text { Social } \\
\text { Sciences }\end{array}$} & 97 & 177 & 143 & 38 & 14 & 1 & 0 & 2 & 472 \\
\hline & $20.6 \%$ & $37.5 \%$ & $30.3 \%$ & $8.1 \%$ & $3.0 \%$ & $0.2 \%$ & $0.0 \%$ & $0.4 \%$ & $100.0 \%$ \\
\hline & .2 & 4.6 & -.2 & -3.4 & -3.2 & -1.8 & -1.1 & .6 & \\
\hline \multirow[t]{2}{*}{ Total } & 353 & 510 & 534 & 217 & 103 & 15 & 3 & 5 & 1740 \\
\hline & $20.3 \%$ & $29.3 \%$ & $30.7 \%$ & $12.5 \%$ & $5.9 \%$ & $0.9 \%$ & $0.2 \%$ & $0.3 \%$ & $100.0 \%$ \\
\hline \multicolumn{10}{|c|}{ Pearson's chi-square: $X^{2}(35)=256.08 ; p<.001$} \\
\hline
\end{tabular}


response from life sciences/medicine is “\$100-\$499" (32.2\%), residual amounts show that they are significantly more likely than expected to choose options between $\$ 500$ and $\$ 3,999$ as reasonable.

If funding were to come from an open access fund through the library, those from arts/ humanities and mathematics are still significantly more likely to select "none" (see table 10). In contrast, a combined 50.2 percent of those from life sciences/medicine have selected an option above $\$ 500$. Every discipline except mathematics has the highest percentage of responses in the " $\$ 100-\$ 499$ " range.

If funding were to come from departmental or other institutional research funds, those from life sciences/medicine are more likely to find APCs between $\$ 500$ and $\$ 3,999$ to be reasonable, while those from arts/humanities are less so (see table 11). Those from among engineering/CS, life sciences/medicine, and physical sciences have the highest percentage of responses within the " $\$ 100-\$ 499$ " range, while those from arts/humanities, mathematics, and social sciences have the highest percentage of responses in the "less than $\$ 100 "$ range.

\begin{tabular}{|c|c|c|c|c|c|c|c|c|c|}
\hline \multicolumn{10}{|c|}{$\begin{array}{c}\text { TABLE } 10 \\
\text { Frequency, Percentage, and Adjusted Standardized Residuals for an Open Access } \\
\text { Fund through the Library }\end{array}$} \\
\hline & \multicolumn{9}{|c|}{ An Open Access Publication Fund through the Library } \\
\hline & None & $\begin{array}{l}\text { Less } \\
\text { than } \\
\$ 100\end{array}$ & $\begin{array}{l}\$ 100 \\
\$ 499\end{array}$ & $\begin{array}{c}\$ 500- \\
\$ 999\end{array}$ & $\begin{array}{c}\$ 1,000- \\
\$ 1,999\end{array}$ & $\begin{array}{c}\$ 2,000- \\
\$ 2,999\end{array}$ & $\begin{array}{c}\$ 3,000- \\
\$ 3,999\end{array}$ & $\begin{array}{l}\$ 4,000 \\
\text { or } \\
\text { more }\end{array}$ & Total \\
\hline \multirow{3}{*}{$\begin{array}{l}\text { Arts/ } \\
\text { Humanities }\end{array}$} & 61 & 114 & 102 & 18 & 8 & 1 & 0 & 2 & 306 \\
\hline & $19.9 \%$ & $37.3 \%$ & $33.3 \%$ & $5.9 \%$ & $2.6 \%$ & $0.3 \%$ & $0.0 \%$ & $0.7 \%$ & $100.0 \%$ \\
\hline & 3.0 & 6.1 & 1.2 & -5.7 & -4.9 & -2.4 & -1.3 & -1.5 & \\
\hline \multirow{3}{*}{$\begin{array}{l}\text { Engineering/ } \\
\text { CS }\end{array}$} & 38 & 48 & 73 & 43 & 14 & 9 & 0 & 3 & 228 \\
\hline & $16.7 \%$ & $21.1 \%$ & $32.0 \%$ & $18.9 \%$ & $6.1 \%$ & $3.9 \%$ & $0.0 \%$ & $1.3 \%$ & $100.0 \%$ \\
\hline & 1.0 & -1.0 & .5 & .8 & -2.2 & 2.1 & -1.1 & -.4 & \\
\hline \multirow{3}{*}{$\begin{array}{l}\text { Life Sci./ } \\
\text { Medicine }\end{array}$} & 58 & 62 & 148 & 129 & 101 & 19 & 8 & 13 & 538 \\
\hline & $10.8 \%$ & $11.5 \%$ & $27.5 \%$ & $24.0 \%$ & $18.8 \%$ & $3.5 \%$ & $1.5 \%$ & $2.4 \%$ & $100.0 \%$ \\
\hline & -2.9 & -8.0 & -1.8 & 5.3 & 7.8 & 2.8 & 4.2 & 1.8 & \\
\hline \multirow[t]{3}{*}{ Mathematics } & 11 & 9 & 7 & 9 & 3 & 0 & 0 & 1 & 40 \\
\hline & $27.5 \%$ & $22.5 \%$ & $17.5 \%$ & $22.5 \%$ & $7.5 \%$ & $0.0 \%$ & $0.0 \%$ & $2.5 \%$ & $100.0 \%$ \\
\hline & 2.4 & -.2 & -1.8 & 1.0 & -.6 & -.9 & -.4 & .4 & \\
\hline \multirow{3}{*}{$\begin{array}{l}\text { Physical } \\
\text { Sciences }\end{array}$} & 17 & 35 & 47 & 29 & 22 & 2 & 0 & 0 & 152 \\
\hline & $11.2 \%$ & $23.0 \%$ & $30.9 \%$ & $19.1 \%$ & $14.5 \%$ & $1.3 \%$ & $0.0 \%$ & $0.0 \%$ & $100.0 \%$ \\
\hline & -1.2 & -.2 & .1 & .7 & 1.8 & -.7 & -.9 & -1.7 & \\
\hline \multirow{3}{*}{$\begin{array}{l}\text { Social } \\
\text { Sciences }\end{array}$} & 66 & 143 & 151 & 65 & 30 & 5 & 0 & 9 & 469 \\
\hline & $14.1 \%$ & $30.5 \%$ & $32.2 \%$ & $13.9 \%$ & $6.4 \%$ & $1.1 \%$ & $0.0 \%$ & $1.9 \%$ & $100.0 \%$ \\
\hline & -.3 & 4.0 & 1.0 & -2.1 & -3.2 & -1.8 & -1.7 & .6 & \\
\hline \multirow[t]{2}{*}{ Total } & \multirow{2}{*}{$\begin{array}{c}251 \\
14.5 \%\end{array}$} & \multirow{2}{*}{$\begin{array}{c}411 \\
23.7 \%\end{array}$} & 528 & 293 & 178 & 36 & 8 & 28 & 1733 \\
\hline & & & $30.5 \%$ & $16.9 \%$ & $10.3 \%$ & $2.1 \%$ & $0.5 \%$ & $1.6 \%$ & $100.0 \%$ \\
\hline
\end{tabular}




\begin{tabular}{|c|c|c|c|c|c|c|c|c|c|}
\hline \multicolumn{10}{|c|}{$\begin{array}{c}\text { TABLE } 11 \\
\text { Frequency, Percentage, and Adjusted Standardized Residuals for Departmental or } \\
\text { Other Institutional Research Funds }\end{array}$} \\
\hline & \multicolumn{8}{|c|}{ Departmental or Other Institutional Research Funds } & \multirow[t]{2}{*}{ Total } \\
\hline & None & $\begin{array}{l}\text { Less } \\
\text { than } \\
\$ 100\end{array}$ & $\begin{array}{l}\$ 100- \\
\$ 499\end{array}$ & $\begin{array}{r}\$ 500- \\
\$ 999\end{array}$ & $\begin{array}{c}\$ 1,000 \\
\$ 1,999\end{array}$ & $\begin{array}{c}\$ 2,000- \\
\$ 2,999\end{array}$ & $\begin{array}{c}\$ 3,000- \\
\$ 3,999\end{array}$ & $\begin{array}{l}\$ 4,000 \\
\text { or } \\
\text { more }\end{array}$ & \\
\hline \multirow{3}{*}{$\begin{array}{l}\text { Arts/ } \\
\text { Humanities }\end{array}$} & 69 & 113 & 97 & 17 & 9 & 2 & 0 & 1 & 308 \\
\hline & $22.4 \%$ & $36.7 \%$ & $31.5 \%$ & $5.5 \%$ & $2.9 \%$ & $0.6 \%$ & $0.0 \%$ & $0.3 \%$ & $100.0 \%$ \\
\hline & 4.2 & 6.0 & .6 & -5.9 & -4.8 & -2.2 & -1.2 & -1.8 & \\
\hline \multirow{3}{*}{$\begin{array}{l}\text { Engineering/ } \\
\text { CS }\end{array}$} & 35 & 41 & 79 & 43 & 18 & 9 & 0 & 4 & 229 \\
\hline & $15.3 \%$ & $17.9 \%$ & $34.5 \%$ & $18.8 \%$ & $7.9 \%$ & $3.9 \%$ & $0.0 \%$ & $1.7 \%$ & $100.0 \%$ \\
\hline & .3 & -2.2 & 1.5 & .8 & -1.4 & 1.6 & -1.0 & .5 & \\
\hline \multirow{3}{*}{$\begin{array}{l}\text { Life Sci./ } \\
\text { Medicine }\end{array}$} & 54 & 63 & 150 & 128 & 103 & 23 & 5 & 8 & 534 \\
\hline & $10.1 \%$ & $11.8 \%$ & $28.1 \%$ & $24.0 \%$ & $19.3 \%$ & $4.3 \%$ & $0.9 \%$ & $1.5 \%$ & $100.0 \%$ \\
\hline & -3.6 & -7.7 & -1.3 & 5.2 & 7.9 & 3.4 & 2.3 & .3 & \\
\hline \multirow[t]{3}{*}{ Mathematics } & 10 & 14 & 6 & 7 & 2 & 1 & 0 & 1 & 41 \\
\hline & $24.4 \%$ & $34.1 \%$ & $14.6 \%$ & $17.1 \%$ & $4.9 \%$ & $2.4 \%$ & $0.0 \%$ & $2.4 \%$ & $100.0 \%$ \\
\hline & 1.8 & 1.6 & -2.2 & .0 & -1.2 & .0 & -.4 & .6 & \\
\hline \multirow{3}{*}{$\begin{array}{l}\text { Physical } \\
\text { Sciences }\end{array}$} & 22 & 28 & 47 & 30 & 22 & 1 & 0 & 2 & 152 \\
\hline & $14.5 \%$ & $18.4 \%$ & $30.9 \%$ & $19.7 \%$ & $14.5 \%$ & $0.7 \%$ & $0.0 \%$ & $1.3 \%$ & $100.0 \%$ \\
\hline & -.1 & -1.6 & .2 & 1.0 & 1.6 & -1.5 & -.8 & -.1 & \\
\hline \multirow{3}{*}{$\begin{array}{l}\text { Social } \\
\text { Sciences }\end{array}$} & 64 & 149 & 144 & 68 & 29 & 6 & 2 & 8 & 470 \\
\hline & $13.6 \%$ & $31.7 \%$ & $30.6 \%$ & $14.5 \%$ & $6.2 \%$ & $1.3 \%$ & $0.4 \%$ & $1.7 \%$ & $100.0 \%$ \\
\hline & -.7 & 4.9 & .3 & -1.6 & -3.6 & -1.9 & .1 & .7 & \\
\hline \multirow[t]{2}{*}{ Total } & 254 & 408 & 523 & 293 & 183 & 42 & 7 & 24 & 1734 \\
\hline & $14.6 \%$ & $23.5 \%$ & $30.2 \%$ & $16.9 \%$ & $10.6 \%$ & $2.4 \%$ & $0.4 \%$ & $1.4 \%$ & $100.0 \%$ \\
\hline
\end{tabular}

Pearson's chi-square: $X^{2}(35)=242.97 ; p<.001$

Finally, if APCs come from grant funds, there is again a significant difference in highest reasonable amount across subject disciplines (see table 12). It seems that the cutoff for those in arts/humanities and social sciences is under $\$ 500$, while more of those from engineering/CS, life sciences/medicine, and physical sciences find it reasonable to pay up to $\$ 1,000$ or higher if the funding comes from a grant. This probably reflects both the likelihood of obtaining grants and the higher typical grant amount in the sciences, medicine, and engineering compared to arts/humanities and social sciences.

\section{Discussion}

Experts agree that open access is here to stay as an increasingly important part of scholarly publishing and communication..$^{55}$ As we have seen, with OA, particularly gold $\mathrm{OA}$, there are as nuanced and varied opinions as there are academic situations. In light of these variances, we have identified six main takeaways for academic libraries at large research institutions to consider. 


\begin{tabular}{|c|c|c|c|c|c|c|c|c|c|}
\hline \multicolumn{10}{|c|}{$\begin{array}{c}\text { TABLE } 12 \\
\text { Frequency, Percentage, and Adjusted Standardized Residuals for Grant Funds }\end{array}$} \\
\hline & \multicolumn{8}{|c|}{ Grant Funds } & \multirow[t]{2}{*}{ Total } \\
\hline & None & $\begin{array}{l}\text { Less } \\
\text { than } \\
\$ 100\end{array}$ & $\begin{array}{l}\$ 100- \\
\$ 499\end{array}$ & $\begin{array}{l}\$ 500- \\
\$ 999\end{array}$ & $\begin{array}{l}\$ 1,000- \\
\$ 1,999\end{array}$ & $\begin{array}{l}\$ 2,000- \\
\$ 2,999\end{array}$ & $\begin{array}{l}\$ 3,000- \\
\$ 3,999\end{array}$ & $\begin{array}{c}\$ 4,000 \\
\text { or } \\
\text { more }\end{array}$ & \\
\hline \multirow{3}{*}{$\begin{array}{l}\text { Arts/ } \\
\text { Humanities }\end{array}$} & 85 & 98 & 89 & 21 & 10 & 3 & 0 & 1 & 307 \\
\hline & $27.7 \%$ & $31.9 \%$ & $29.0 \%$ & $6.8 \%$ & $3.3 \%$ & $1.0 \%$ & $0.0 \%$ & $0.3 \%$ & $100.0 \%$ \\
\hline & 6.6 & 4.5 & .1 & -5.0 & -5.2 & -2.6 & -1.5 & -1.4 & \\
\hline \multirow{3}{*}{$\begin{array}{l}\text { Engineering/ } \\
\text { CS }\end{array}$} & 29 & 47 & 78 & 46 & 13 & 9 & 3 & 4 & 229 \\
\hline & $12.7 \%$ & $20.5 \%$ & $34.1 \%$ & $20.1 \%$ & $5.7 \%$ & $3.9 \%$ & $1.3 \%$ & $1.7 \%$ & $100.0 \%$ \\
\hline & -1.2 & -.7 & 1.9 & 1.5 & -3.2 & .5 & 1.4 & 1.1 & \\
\hline \multirow{3}{*}{$\begin{array}{l}\text { Life Sci./ } \\
\text { Medicine }\end{array}$} & 48 & 61 & 133 & 123 & 125 & 35 & 6 & 8 & 539 \\
\hline & $8.9 \%$ & $11.3 \%$ & $24.7 \%$ & $22.8 \%$ & $23.2 \%$ & $6.5 \%$ & $1.1 \%$ & $1.5 \%$ & $100.0 \%$ \\
\hline & -5.0 & -7.3 & -2.5 & 4.7 & 9.5 & 4.8 & 1.7 & 1.2 & \\
\hline \multirow[t]{3}{*}{ Mathematics } & 10 & 12 & 8 & 7 & 3 & 1 & 0 & 0 & 41 \\
\hline & $24.4 \%$ & $29.3 \%$ & $19.5 \%$ & $17.1 \%$ & $7.3 \%$ & $2.4 \%$ & $0.0 \%$ & $0.0 \%$ & $100.0 \%$ \\
\hline & 1.6 & 1.1 & -1.3 & .1 & -.9 & -.3 & -.5 & -.7 & \\
\hline \multirow{3}{*}{$\begin{array}{l}\text { Physical } \\
\text { Sciences }\end{array}$} & 20 & 32 & 44 & 28 & 24 & 5 & 0 & 1 & 154 \\
\hline & $13.0 \%$ & $20.8 \%$ & $28.6 \%$ & $18.2 \%$ & $15.6 \%$ & $3.2 \%$ & $0.0 \%$ & $0.6 \%$ & $100.0 \%$ \\
\hline & -.9 & -.5 & .0 & .6 & 1.4 & -.1 & -1.0 & -.5 & \\
\hline \multirow{3}{*}{$\begin{array}{l}\text { Social } \\
\text { Sciences }\end{array}$} & 76 & 137 & 148 & 63 & 35 & 6 & 2 & 4 & 471 \\
\hline & $16.1 \%$ & $29.1 \%$ & $31.4 \%$ & $13.4 \%$ & $7.4 \%$ & $1.3 \%$ & $0.4 \%$ & $0.8 \%$ & $100.0 \%$ \\
\hline & .5 & 4.2 & 1.5 & -2.2 & -3.6 & -3.0 & -.7 & -.5 & \\
\hline \multirow[t]{2}{*}{ Total } & 268 & 387 & 500 & 288 & 210 & 59 & 11 & 18 & 1741 \\
\hline & $15.4 \%$ & $22.2 \%$ & $28.7 \%$ & $16.5 \%$ & $12.1 \%$ & $3.4 \%$ & $0.6 \%$ & $1.0 \%$ & $100.0 \%$ \\
\hline
\end{tabular}

Six main takeaways identified:

1. The prevailing attitude toward open access is often ambivalence.

2. Faculty are often conservative in their acceptance of OA.

3. Applied STEM fields are more accepting of OA.

4. Willingness to pay varies by source of funding.

5. Ambivalence provides a teachable moment for libraries.

6. Funding for APCs can be crucial for libraries.

\section{The prevailing attitude toward open access is ambivalence.}

A majority of survey respondents did not express strong opinions either for or against open access. When asked their general opinions concerning the quality of OA journals, the reasonableness of APCs, and whether APCs reflect the quality of an OA journal, the mean response was neutral. When asked for a level of agreement on the statement ( 1 = disagree strongly and 5 = agree strongly), "In general, articles published in Open Access journals are of lower quality than those published in subscription-based journals," 24 percent of respondents $(352$ of 1,443$)$ were absolutely neutral $(\mathrm{M}=3.00)$ on the perceived quality of OA journals. Only 17 percent strongly disagreed (248), while 
19 percent leaned toward disagreement (269) and 13 percent strongly agreed (184), with 27 percent leaning toward agreement (390) with this statement. This breakdown shows that respondents did often possess strong feelings toward OA, though may lean toward negative views. The strong strain of ambivalence that runs through respondent attitudes toward OA denotes an ambivalence toward the entire endeavor and may be due, partly, to confusion about the different types of OA. ${ }^{56}$ It may be the result of their uncertainty about how the adoption of gold OA may affect their publishing opportunities. This uncertainty is borne out by their slight disagreement over APCs.

Survey respondents lean slightly toward disagreement whether the amount of APCs reflects the quality of the journal and on the reasonableness of APCs as an alternative to subscription fees. They worry about the impact of APCs for researchers at smaller institutions. It seems to set researchers from well-funded institutions and/ or disciplines at a distinct advantage over their lower-funded colleagues. There is a sense that it goes against the idea of the scientific or research process as inherently altruistic or democratic. ${ }^{57}$ On the other hand, respondents generally like the idea that their research would be more widely available.

\section{Faculty are more conservative in their acceptance of gold $\mathrm{OA}$.}

As we have seen, there are career generational differences in regard to the acceptance of OA, particularly gold OA. ${ }^{58}$ On average, faculty at these types of universities tend to hold more conservative and negative opinions. Compared to graduate students and postdocs, faculty respondents, in general, believe that OA is lower quality and that quality would not increase with the adoption of gold OA. This may be because tenured faculty came of age (careerwise) before the advent of OA and other new publishing models. Moreover, as Lewis notes, senior researchers have little incentive to change their publication habits because they are already established..$^{59}$ On the other hand, postdocs, early in their careers, are far more accepting of gold OA. This acceptance may be supported by their greater access to research funds and grants by virtue of their positions. In addition, faculty are also more aware of about possible negative impact for researchers at smaller institutions. They are more aware of the pitfalls of conducting research at these smaller or less well-funded institutions than their younger counterparts. Again, this finding may be tied to personal and professional experience.

\section{Applied STEM fields are more accepting of $\mathrm{OA}$.}

There are disciplinary differences at these universities in the general acceptance of gold OA as well. Respondents in the life sciences and medicine and engineering on average express more positive opinions - particularly in regard to quality and outreach. This difference may also be due to the higher number of practitioner audiences in these fields (such as municipal civil engineers and practicing physicians). For these fields, outreach is of greater importance, which is reflected by their agreement in regard to the possible increase in readership..$^{60}$ Their disciplines may rely upon the ability of practitioner audience to easily access and implement the findings of research in the field. Practitioner audiences often do not have the funds for subscriptions beyond professional journals. In addition, many fields, including practitioner fields, are under increasing pressure to make publicly funded research open access. ${ }^{61}$ Therefore, OA may be critical.

Respondents in engineering and life/medical sciences are more likely to believe that more people would read their work and that there would be more media coverage in a gold OA world. These fields also tend to be better funded and are in a better position to afford higher APCs. ${ }^{62}$ It is unsurprising, then, that engineering and life/ medical sciences tend to believe more strongly that APCs are a reasonable alternative 
to the subscription model. Likewise, lower-funded disciplines in the arts/humanities and social sciences feel that gold OA may hinder their ability to publish. They are also, on average, more worried about the impact that gold OA may have on the ability and opportunity of those with less funding to publish-whether that is due to smaller institutions or disciplinary differences in funding. In fact, they are more willing to explore alternative publishing outlets.

\section{Willingness to pay varies by source of funding.}

The maximum amount that respondents at these universities cite as willing to pay varies by source of funding. However, it is important to note that most respondents do not wish to pay more than $\$ 100$. They are particularly reluctant to pay APCs through their personal or private funds. This finding is especially true for those from the arts/ humanities, who may have less funding from which to draw. ${ }^{63}$ Again, researchers from traditionally better-funded disciplines are more willing to pay-and to pay more. For example, those from life sciences and medicine are the only respondents willing to pay more than $\$ 2,000$ per APC.

\section{Ambivalence provides a teachable moment for libraries.}

The ambivalence of researchers toward OA can serve as a teachable moment for libraries. Libraries can take the opportunity to lead conversations about OA their institutions. Or, if they wish, they can advocate for researchers and show them where libraries can support this facet of their research process as well. ${ }^{64}$ After all, as Fruin and Rascoe note in their examination of potential sources of funding for APCs, libraries are often (and traditionally) seen as a "primary resource" for their institutions on scholarly communication. ${ }^{65}$ They can use this to influence the role of libraries in scholarly communications by providing funding opportunities for researchers if the standard publishing model becomes gold OA. Because APCs remain controversial and often contribute to confusion between gold OA and predatory journals, the library's role as educator can be important in the academy. ${ }^{66}$ Libraries may also bridge the gap between generational and discipline differences by providing workshops or seminars targeting specific populations. As Ogden has advocated, open access provides a unique opportunity for librarians to forge new collaborative partners across campus to meet this educational need - both for their faculty and student populations. ${ }^{67}$

\section{Funding for article processing charges can be crucial to libraries.}

Funding for article processing charges can be crucial to libraries. As the publishing world moves toward developing a more widespread system of gold OA, libraries may be trading subscription models for APC funding models to support their researchers' publishing endeavors directly, ${ }^{68}$ in which case the library's role as potential funder becomes increasingly important. Fruin and Rascoe note that libraries may reallocate collection budgets to include funding for APCs. ${ }^{69}$ This reallocation would presumably draw from those reserved for subscriptions. In her examination of the economics of open access publishing, Morrison points out that APC funding may not wholly reside with the library. ${ }^{70}$ Eckman and Weil call for an institutional or library-based APC fund. ${ }^{71}$ A more practical solution may be a partnership between the library and the institution as a whole, underscoring again the need for libraries to forge new collaborative relationships. As we have stated, the library as a source of APC funding was polarizing within the survey. Thirty-one percent of respondents do not expect or feel that the library should contribute anything to APC funding, while one-quarter believe that $\$ 2,000-\$ 2,999$ is a reasonable amount. However, one-third of respondents across the disciplines feel that between $\$ 100$ and $\$ 499$ is a reasonable amount of support to 
expect from libraries regarding APCs. However, certain disciplines such as life sciences and medicine may expect as much as $\$ 4,000$ or more to be a reasonable amount to be covered by a library-based OA fund. It is clear that academics are interested in what role libraries may play in the funding of gold OA publishing models, ${ }^{72}$ perhaps most especially how libraries may aid researchers in less well-funded disciplines to publish in these journals. ${ }^{73}$

\section{Conclusion}

The proliferation of open access provides opportunities for academic libraries to forge new relationships with their research communities and institutions and to develop services and outreach uniquely suited to the changing scholarly communication landscape. In a budget-conscious world that demands libraries justify their expenditure-even their existence-finding new ways to support research and researchers must be a priority. This is critical if libraries are to remain relevant to the academy. Our takeaways highlight areas in which libraries may act-such as education, outreach, and funding. This nexus of scholarly communication and information literacy is rooted in librarians' traditional roles as advocates and educators, reinforcing the library's place at the heart of scholarship. Moreover, it addresses the practical concerns of funding. However, as our study focused on large, research-intensive universities, further research at smaller institutions is needed.

\section{Acknowledgements}

The Pay It Forward project was funded by the Andrew W. Mellon Foundation through a grant to the University of California-Davis. We would also like to acknowledge our gratitude toward our survey respondents for their input. We also thank the efforts of: Ivy Anderson (CDL), Sheldon Armstrong (UBC), Bo-Christer Bjørk (Hanken), Laine Farley (CDL), Dracine Hodges (OSU), Mark McCabe (BU), Elke Piontek (Harvard), Jo Anne Newyear Ramirez (UBC), John P. Renaud (UCI), Karla Strieb (OSU), Greg Tananbaum (Scholar Next), Scott Wicks (Harvard), and Mathew Wilmott (CDL).

\section{Notes}

1. Heather Joseph, "The Open Access Movement Grows Up: Taking Stock of the Revolution," PLoS Biology 11, no. 10 (2013), doi:10.1371/journal.pbio.1001686; David W. Lewis, "The Inevitability of Open Access," College E Research Libraries 73, no. 5 (2012): 493-506, doi:10.5860/crl-299; Roger C. Schonfeld, "Scholarly Societies and Scholarly Communication: A Look Ahead," College $\mathcal{E}$ Research Libraries 76, no. 3 (2015): 406-10, doi:10.5860/crl.76.3.406.

2. Jason Hoyt and Peter Binfield, "Everything Evolves, Even Publishing," Against the Grain 28, no. 1 (2016): 25.

3. Linlin Zhao, "Riding the Wave of Open Access: Providing Library Research Support for Scholarly Publishing Literacy," Australian Academic E Research Libraries 45, no. 1 (2014): 2-18, do i:10.1080/00048623.2014.882873.

4. Schonfeld, "Scholarly Societies and Scholarly Communication"; Audra K. Roach and Jesse Gainer, "On Open Access to Research: The Green, the Gold, and the Public Good," Journal of Adolescent \& Adult Literacy 56, no. 6 (2013): 530-34, doi:10.1002/JAAL.177; Intekhab Alam, "Changing Role of Academic Librarians in Open Access Environment," Journal of Library \& Information Science 4, no. 4 (2014): 449-57.

5. Roach and Gainer, "On Open Access to Research."

6. Alam, "Changing Role of Academic Librarians"; Heather Morrison, "Economics of Scholarly Communication in Transition," First Monday 18, no. 6 (June 2013), doi:10.5210/fm.v18i6.4370.

7. William H. Mischo and Mary C. Schlembach, "Open Access Issues and Engineering Faculty Attitudes and Practices," Journal of Library Administration 51, no. 5/6 (2011): 432-54, doi:10.108 0/01930826.2011.589349; Edda T. Lwoga and Frederik Questier, "Open Access Behaviours and Perceptions of Health Sciences Faculty and Roles of Information Professionals," Health Information $\mathcal{E}$ Libraries Journal 32, no. 1 (2015): 37-49, doi:10.1111/hir.12094. 
8. Maggie Farrell and Alicia Wise, "Adaptations in Publishing: Publishers and Librarians Advancing Research," Against the Grain 28, no. 1 (Feb. 2016): 28-30; Maria Bonn, "Tooling Up: Scholarly Communication Education and Training," College E Research Libraries News 75, no. 3 (Mar. 1, 2014): 132-35.

9. Kara J. Malenfant, "Leading Change in the System of Scholarly Communication: A Case Study of Engaging Liaison Librarians for Outreach to Faculty," College \& Research Libraries 71, no. 1 (2010): 63-76, doi:10.5860/crl.76.3.392; Farrell and Wise, "Adaptations in Publishing"; Bonn, "Tooling Up."

10. University of California Libraries, "Pay It Forward: Investigating a Sustainable Model of Open Access Article Processing Charges for Large North American Research Institutions" (2016), available online at http://icis.ucdavis.edu/wp-content/uploads/2016/07/UC-Pay-It-Forward-FinalReport.rev_.7.18.16.pdf [accessed 1 July 2016].

11. Jingfeng Xia, "A Longitudinal Study of Scholars Attitudes and Behaviors toward Open Access Journal Publishing," Journal of the American Society for Information Science and Technology 61, no. 3 (2010): 615-24, doi:10.1002/asi.21283; David Nicholas, Paul Huntington, and Ian Rowlands, "Open Access Journal Publishing: The Views of Some of the World's Senior Authors," Journal of Documentation 61, no. 4 (2005): 497-519, doi:10.1108/00220410510607499; Anthony Watkinson, David Nicholas, Clare Thornley, Eti Herman, Hamid R. Jamali, Rachel Volentine, Suzie Allard, Kenneth Levine, and Carol Tenopir, "Changes in the Digital Scholarly Environment and Issues of Trust: An Exploratory, Qualitative Analysis," Information Processing and Management (2015), doi:10.1016/j.ipm.2015.10.002.

12. Jeffrey Beall, "Predatory Publishing Is Just One of the Consequences of Gold Open Access," Learned Publishing 26, no. 2 (2013): 79-83, doi:10.1087/20130203.

13. Declan Butler, "Investigating Journals: The Dark Side of Publishing," Nature 495, no. 7442 (2013): 433-35.

14. Zhao, "Riding the Wave of Open Access."

15. Stefanie E. Warlick and KLT Vaughan, "Factors Influencing Publication Choice: Why Faculty Choose Open Access," Biomedical Digital Libraries 4, no. 1 (2007), doi:10.1186/1742-5581-4-1.

16. Mischo and Schlembach, "Open Access Issues"; William H. Walters, "Institutional Journal Costs in an Open Access Environment," Journal of the American Society for Information Science $\mathcal{E}$ Technology 58, no. 1 (2007): 108-20, doi:10.1002/asi.20441.

17. Malenfant, "Leading Change in the System of Scholarly Communication."

18. Zhao, "Riding the Wave of Open Access."

19. Association of College and Research Libraries, Working Group on Intersections of Scholarly Communication, and Information Literacy, Intersections of Scholarly Communication and Information Literacy: Creating Strategic Collaborations for a Changing Academic Environment (2013), 14, available online at http://acrl.ala.org/intersections/ [accessed 2 April 2016]; Common Ground at the Nexus of Information Literacy and Scholarly Communication, eds. Stephanie Davis-Kahl and Merinda Kaye Hensley (Chicago, Ill.: Association of College \& Research Libraries, 2013); Joyce L. Ogburn and Merinda Kaye Hensley, "Bringing Together the Educator and the Advocate: A Report from the ACRL Task Force on the Intersections of Scholarly Communication and Information Literacy," College E Research Libraries News 76, no. 9 (Oct. 1, 2015): 509.

20. Maria Bonn, "Tooling Up: Scholarly Communication Education and Training," College $\mathcal{E}$ Research Libraries News 75, no. 3 (Mar. 1, 2014): 132-35.

21. William Joseph Thomas, "The Structure of Scholarly Communications within Academic Libraries," Serials Review 39, no. 3 (Sept. 1, 2013): 167-71, doi:10.1080/00987913.2013.10766387; Morrison, "Economics of Scholarly Communication in Transition"; Walters, "Institutional Journal Costs in an Open Access Environment."

22. Carol Tenopir, Betsy D. Dalton, and Misty K. Jones, "Pay It Forward: Investigating a Sustainable Model of Open Access Article Processing Charges for Large North American Research Institutions Survey Instrument" (2015), School of Information Sciences: Faculty Publications and Other Works, available online at http://trace.tennessee.edu/utk_infosciepubs/48 [accessed 16 January 2016].

23. Carol Tenopir, Elizabeth Dalton, Allison Fish, Lisa Christian, Misty Jones, and MacKenzie Smith. "What Motivates Authors of Scholarly Articles? The Importance of Journal Attributes and Potential Audience on Publication Choice," Publications 4, no. 3 (2016), doi:10.3390/publications4030022.

24. The MANOVA (multiple analysis of variance) test can be used to look at differences across a group of items that are topically related but do not necessarily comprise a validated scale. The advantage, versus only looking at individual items with single ANOVAs, is that the omnibus test first reduces the risk of Type I error by excluding answers from those who did not answer each item within the grouping. Therefore, we chose this test to look at "opinions" and "scenarios" as aggregate groups of related items at once. 
25. Tukey's HSD: $P<.001$.

26. Tukey's HSD: $P=.004$.

27. Tukey's HSD: $P=.001$.

28. Tukey's HSD: $P<.001$.

29. Tukey's HSD: $P=.003$.

30. Tukey's HSD for engineering/computer science, life sciences/medicine, and physical sciences all $P<.001$.

31. Tukey's HSD: $P=.001$.

32. Tukey's HSD: $P<.001$.

33. Tukey's HSD: $P<.001$.

34. Tukey's HSD: $P<.001$.

35. Tukey's HSD: $P=.006$.

36. Tukey's HSD: $P=.001$.

37. Tukey's HSD: $P<.001$.

38. Tukey's HSD: $P=.001$.

39. Tukey's HSD: arts/humanities $P<.001$, social science $P=.009$.

40. Tukey's HSD: arts/humanities $P<.001$, social science $P=.002$.

41. Tukey's HSD: $P<.001$.

42. Tukey's HSD: $P=.009$.

43. Tukey's HSD: $P=.007$.

44. Tukey's HSD: $P=.010$.

45. Tukey's HSD: $P<.001$.

46. Tukey's HSD: $P=.001$.

47. Tukey's HSD: $P=.001$.

48. Tukey's HSD: $P=.030$.

49. Tukey's HSD: $P=.008$.

50. Tukey's HSD: $P=.002$.

51. Tukey's HSD: $P=.006$.

52. Tukey's HSD: $P=.014$.

53. Tukey's HSD: $P=.023$.

54. Donald Sharpe, "Your Chi-Square Test Is Statistically Significant: Now What?" Practical Assessment, Research and Evaluation 20, no. 8 (2015), available online at http://pareonline.net/getvn. asp? $\mathrm{v}=20 \& \mathrm{n}=8$ [accessed 16 January 2016]. cess."

55. Joseph, "The Open Access Movement Grows Up"; Lewis, “The Inevitability of Open Ac-

56. Dominguez, Magaly Báscones. “Economics of Open Access Publishing.” Serials 19, no. 1 (2006): 52-60.

57. Terry Sunderland, Jacqueline Sunderland-Groves, Patricia Shanley, and Bruce Campbell, "Bridging the Gap: How Can Information Access and Exchange between Conservation Biologists and Field Practitioners Be Improved for Better Conservation Outcomes?" Biotropica 41, no. 5 (2009): 549-54, doi:10.1111/j.1744-7429.2009.00557.x; Roach and Gainer, "On Open Access to Research."

58. Elaine Nowick, "Academic Rank of Authors Publishing in Open Access Journals," Faculty Publications, UNL Libraries (2008): 180; Christie Hurrell and Karen Meijer-Kline, "Open Access up for Review: Academic Attitudes Towards Open Access Publishing in Relation to Tenure and Promotion," Open Excess 1, no. 2 (2011).

59. Lewis, "The Inevitability of Open Access."

60. Bo-Christer Björk, Patrik Welling, Mikael Laakso, Peter Majlender, Turid Hedlund, and Guðni Guðnason, "Open Access to the Scientific Journal Literature: Situation 2009," PLoS ONE 5, no. 6 (2010): e11273, doi:10.1371/journal.pone.0011273; Leslie Chan, Barbara Kirsop, Sely Maria de Souza Costa, and Subbiah Arunachalam, "Improving Access to Research Literature in Developing Countries: Challenges and Opportunities Provided by Open Access." in IFLA General Conference and Council (Oslo, Norway, 2005); Josefina Coloma and Eva Harris, "Open-Access Science: A Necessity for Global Public Health," PLoS Pathog 1, no. 2 (2005): e21, doi:10.1371/journal. ppat.0010021; Sunderland et al., "Bridging the Gap."

61. Christine Fruin and Fred Rascoe, "Funding Open Access Journal Publishing Article Processing Charges," College \& Research Libraries News 75, no. 5 (2014): 243; Stephanie Tzarnas and Chris D. Tzarnas, "Publish or Perish, and Pay: The New Paradigm of Open-Access Journals," Journal of Surgical Education 72, no. 2 (2015): 283-85, doi:10.1016/j.jsurg.2014.09.006.

62. Aspasia Togia and Stella Korobili, "Attitudes Towards Open Access: A Meta-Synthesis of the Empirical Literature," Information Services \& Use 34, no. 3/4 (2014): 221-31, doi:10.3233/ISU140742.

63. Ibid.; Martin Paul Eve, Open Access and the Humanities (Cambridge, United Kingdom: Cambridge University Press, 2014). 
Imagining a Gold Open Access Future 843

64. Farrell and Wise, "Adaptations in Publishing."

65. Fruin and Rascoe, "Funding Open Access Journal Publishing Article Processing Charges."

66. Dominguez, "Economics of Open Access Publishing."

67. Ogburn and Hensley, "Bringing Together the Educator and the Advocate."

68. Thomas, "The Structure of Scholarly Communications."

69. Fruin and Rascoe, "Funding Open Access Journal Publishing Article Processing Charges."

70. Morrison, "Economics of Scholarly Communication."

71. Charles D. Eckman and Beth T. Weil, "Institutional Open Access Funds: Now Is the Time," PLoS Biol 8, no. 5 (2010), doi:10.1371/journal.pbio.1000375.

72. Mischo and Schlembach, "Open Access Issues."

73. Morrison, "Economics of Scholarly Communication." 